\title{
Фортепіанна надійність студентів факультетів мистецтв педагогічних університетів у психолого-педагогічному аспекті
}

\begin{abstract}
Розглянуто сутність фортепіанної надійності студентів факультетів мистецтв педагогічних університетів. Визначено актуальність проблеми у контексті чітко окресленої освітньої тенденції щодо перманентної оптимізації фахового навчання майбутніх педагогів-музикантів, активізації новаційних технологій у галузі педагогіки мистецтва, методичного оновлення педагогічної науки. Встановлено, що нездатність майбутніх фахівців-музикантів до якісного фортепіанного виконавства може призвести до невиправданих вад і недоліків у процесі подальшої фахової діяльності. Надійність музичного виконавства окреслено як невід'ємну складову виконавської майстерності музиканта-інструменталіста. Наведено й проаналізовано визначення й зміст виконавської надійності майбутнього педагога-музиканта провідними сучасними дослідниками. Досліджено вплив стресових ситуацій на якість фортепіанного гри у процесі прилюдної виконавської діяльності. Доведено, що надійність виконання студентом фортепіанних творів залежить від його психолого-емоційної сфери, яка відповідає за сценічну поведінку особистості, адаптуючи іiі до емоціогенних умов оприлюднення результатів попередньої роботи. Розкрито зміст двох основних різновидів емоційного стресу - евстресу й дистресу. Подано основні кроки формування фортепіанної надійності у площині цілеспрямованої організації особистісно-орієнтованого фортепіанного навчання студентів. Створено авторське визначення досліджуваного феномену як набутої в процесі фортепіанного навчання інтегральної якості студентів факультетів мистецтв педагогічних університетів, яка забезпечує в емоційно-стресових умовах прилюдної фортепіанної гри повноцінне й ефективне виконання завдань, поставлених під час попередньої фортепіанної підготовки з метою результативного розкриття художньо-образного змісту музичного твору.

Ключові слова: виконавська надійність; студенти факультетів мистецтв педагогічних університетів; емоційний стрес; евстрес; дистрес; особистісно-орієнтоване фортепіанне навчання.
\end{abstract}

Актуальність теми. В сучасних умовах докорінного реформування мистецької освіти в Україні, які спричинили іiі оновлення, призвели до активізації розвитку й уможливили збагачення методичного забезпечення процесу мистецького навчання, чітко окреслилась тенденція щодо необхідності термінової відповіді на потреби суспільства у царині підвищення фахової компетентності педагогічних кадрів. У той же час світові освітні тенденції (в країнах Свропейського Союзу, Китаї, Сполучених Штатах Америки тощо) також демонструють стійкі пріоритети щодо перманентної оптимізації фахового навчання майбутніх педагогів-музикантів, які накладають конкретний відбиток на активізацію новаційних технологій педагогіки мистецтва, на постійне методичне оновлення педагогічної науки.

У галузі музичної педагогіки та виховання багаторічним трендом сучасних досліджень $\epsilon$ пошук ефективних методів, засобів, прийомів i форм як музичного сприймання, так i відтворення музичного матеріалу. Зокрема, проблема формування саме фортепіанної надійності студентів факультетів мистецтв педагогічних університетів вимагає якісного концептуального вирішення. Адже фортепіанна гра для студентів вищих музичнопедагогічних закладів $є$ необхідним елементом фаху вчителя музичного мистецтва або викладача мистецьких дисциплін, які здобуваються в результаті навчання у бакалавраті та магістратурі педагогічних університетів.

Актуальність формування надійності фортепіанного виконавства для майбутніх педагогів-музикантів $\epsilon$ аксіоматичною, оскільки фортепіанна гра використовується як у процесі уроків мистецтва під час розспівування учнів, розучування пісенного матеріалу, персонального показу вчителем музичних творів для слухання тощо, так і у позаурочній діяльності у режимі організації й забезпечення колективного музикування учнів, просвітницько-концертної роботи та ін. Нездатність майбутніх фахівців-музикантів до якісного фортепіанного виконавства у разі, якщо фортепіанна надійність залишиться 
несформованою, може призвести до невиправданих вад і недоліків безпосередньо у процесі фахової діяльності.

Проблематика надійності музичного виконавства була предметом досліджень багатьох вчених і практикуючих педагогів минулого й сучасності, які працювали у галузях музичної педагогіки загалом і фортепіанної педагогіки зокрема, музичної психології, музикознавства, теорії та методики музичного навчання тощо. Зокрема, Л.Баренбойм, Л.Гінзбург, Г.Коган, Л.Маккіннон, Г.Нейгауз, С.Савшинський, Л.Оборін, Г.Хуст та ін. розглядали цю проблему у контексті формування майстерності музичного виконавства. Причому надійність музичного виконавства визначалась ними як невід’ємна складова означеної майстерності музикантаінструменталіста.

Психолого-педагогічні аспекти проблеми формування виконавської надійності були висвітлені у працях Л.Бочкарьова, А.Готсдінера, Л.Котової, В.Муцмахера, О.Олексюк, Д.Юника, Т.Юник та ін. Теоретико-методологічні й методичні засади формування цього феномену досліджували М.Давидов, Т.Грізоглазова, Л.Котова, Д.Юник, Т.Юник, Ю.Цагареллі, Г.Ципін та ін. Утім, багата палітра креативних ідей, науково-методичних концепцій, методичних розробок вимагають подальшого системно-структурного розв'язання досліджуваної проблеми.

Метою статті $є$ теоретичне обгрунтування й визначення сутності феномену фортепіанної надійності студентів факультетів мистецтв педагогічних університетів у психолого-педагогічному аспекті.

Д.Юник, який здійснив суттєвий внесок у розроблення сучасних методичних засад формування музично-виконавської надійності студентів факультетів мистецтв педагогічних університетів, визначає цей феномен як «...не вроджену, а набуту інтегральну властивість, яка забезпечує безпомилкове і точне виконання музичних творів у звичних і емоціогенних умовах сценічної діяльності» [3, 118]. Дослідник обгрунтовує й встановлює основні чинники забезпечення в студентів досліджуваного феномену, до яких відносить: - досконалість підготовки концертної програми; - здатність до саморегуляції процесу виконавської діяльності; - сформовану завадостійкість до надмірної дії стресорів [3, 118].

Л.Котова, беручи до уваги концептуальні положення виконавської надійності, розроблені Ю.Цагареллі [2], стверджує значущість для формування цього феномену такого чинника, як емоційна стійкість. Авторка зазначає, що «...в умовах підвищеної психологічної напруги, яка виникає під час прилюдних виступів, емоційна стійкість особистості складає основу виконавської надійності музикантів, оскільки ... саме емоційна стійкість сприяє збереженню результативності будь-якої діяльності в емоціогенних ситуаціях» $[1,5]$.

Ми погоджуємось із думкою дослідниці стосовно того, що підгрунтям для формування у студентів-інструменталістів музично-виконавської надійності $\epsilon$ «..чіткі уявлення засвоєної інформації у вигляді образів структури дій та активної вольової участі в корекції психічних станів» $[1,5]$.

Отже, аналіз науково-теоретичних джерел 3 досліджуваної проблеми дозволяє констатувати, що дотичними до іiї розв'язання виступають такі поняття, пов'язані 3 психологічною сферою особистості, як емоційна стійкість, саморегуляція процесу виконавської діяльності, завадостійкість, дія стресорів тощо. Тобто з метою визначення сутності поняття «фортепіанна надійність студентів факультетів мистецтв педагогічних університетів» доцільно розглянути цю проблему в психоло-педагогічному аспекті, зокрема, дослідивши вплив стресових ситуацій на якість фортепіанного гри у процесі прилюдної виконавської діяльності.

Вивчення питання впливу стресових ситуацій в теорії та методиці фортепіанної педагогіки засвідчує, що надійність виконання студентом фортепіанних творів залежить від його психолого-емоційної сфери, яка власне і відповідає за сценічну поведінку особистості, адаптуючи iї до емоціогенних умов оприлюднення результатів попередньої роботи. Від 
сформованості психологічної здатності студента до такої адаптації і залежить рівень виконавської діяльності.

Педагогічне спостереження за сценічною поведінкою студентів під час екзаменів і заліків 3 навчальних дисциплін «Основний інструмент», «Додатковий інструмент», а також під час концертів дозволяє стверджувати, що такі подразники, як екзаменаційна комісія, публіка в залі і навіть дитяча аудиторія на уроках мистецтва в загальноосвітній школі викликають у студентів емоційний стрес, у результаті чого відбуваються «випадіння» 3 пам'яті окремих елементів музичного твору, необгрунтоване прискорення або уповільнення темпу, втрати операційно-технічного характеру тощо.

На нашу думку, емоційний стрес $є$ специфічною психологічною формою реагування особистості на складну, відповідальну або впливово-визначальну для неї ситуацію, яка супроводжується потужним викидом складного комплексу емоцій, що змінюють оперативні можливості організму.

Серед науковців існують два погляди щодо впливу емоційного стресу на надійність музичного виконавства. Ряд дослідників, музикознавців, педагогів, серед яких: М.Азавашвілі, І.Андроніков, В.Антонюк, Н.Гребенюк, Г.Нейгауз, Т.Юник та ін., зазначає переважно негативний вплив підвищеної емоційної інтенсивності на надійність процесу виконання музичних творів. На бінарності впливу емоційного стресу наполягають такі вчені, виконавціпрактики, як Л.Аболін, О.Дашкевич, Е.Носенко, Д.Ойстрах, І.Пацявічус, Г.Сельє, А. Тимченко та ін. Ці дослідники відмічають як переваги, так і недоліки впливу емоційних стресів на процес музичного виконавства.

Причому один з різновидів емоційного стресу - евстрес - дозволяє молодому піаністові мобілізуватись, виявити найкращі свої досягнення попередньої фортепіанної підготовки i навіть втілити музичний образ яскравіше, ніж під час поточних занять із викладачем. 3 іншого боку, такий різновид емоційного стресу як дистрес провокує у студента або активізацію гальмування операційно-технічних реакцій, або, навпаки, їх безконтрольне прискорення, що супроводжується панічними станами у виконавському процесі, втратою саморегулювання й веде іноді до виконавського «зриву».

На нашу думку, відповідь на запитання щодо впливу емоційних стресів на формування фортепіанної надійності студентів факультетів мистецтв педагогічних університетів знаходиться у площині цілеспрямованої організації особистісно-орієнтованого фортепіанного навчання студентів, що передбачає з боку професорсько-викладацького складу наступні кроки:

- на основі ретельного педагогічного спостереження й аналізу його результатів складання особистісного психологічного портрету кожного із студентів, який стосується психотипу, характерних властивостей емоційних реакцій на стресові подразники, особливостей сценічної поведінки, здатності до саморегулювання у процесі оприлюднення результатів фортепіанної підготовки;

- розроблення педагогічного репертуару з урахуванням як тактичних, так і стратегічних завдань формування фортепіанної надійності, який забезпечить мінімізацію ризиків негативних явищ прилюдного виконання фортепіанних творів;

- залучення сугестивних технологій до методичного забезпечення фортепіанної надійності студентів факультетів мистецтв педагогічних університетів 3 метою розвитку впевненості у своїх творчих можливостях;

- створення спеціальних умов у навчальному середовищі для систематичного впровадження практики фортепіанного виконавства у процесі фортепіанної підготовки студентів, що уможливить процеси звикання до прилюдної інструментальної діяльності.

3 огляду на вищезазначене, психолого-педагогічний аспект розгляду фортепіанної надійності у контексті впливу емоційного стресу дозволив визначити досліджуваний феномен в якості набутої в процесі фортепіанного навчання інтегральної якості студентів факультетів мистецтв педагогічних університетів, яка забезпечує в емоційно-стресових 
умовах прилюдної фортепіанної гри повноцінне й ефективне виконання завдань, поставлених під час попередньої фортепіанної підготовки з метою результативного розкриття художньообразного змісту музичного твору.

\section{Література}

1. Антонова О.С. Теоретичні та методичні засади навчання педагогічно обдарованих студентів. Житомир : Вид-во ЖДУ імені І.Франка, 2007.471с.

2. Бурська О.П. Методичні основи розвитку музично-виконавського мислення студентів у проиесі фортепіанної підготовки: Дис.... канд. пед. наук:13.00.02 / О.П. Бурська. - Вінниця : Вінницький держ. пед. ун-т ім.

М. Коцюбинського, 2004. 239c.

3. Грінчук І., Бурська О. Проблеми музичного мислення: теорія $і$ методика розвитку : Навч.метод. посібник / І. Грінчук, О. Бурська. - Тернопіль: Підручники і посібники, 2008. 224c.

4. Гуральник Н.П. Імпровізаційні уміння майбутнього вчителя музики в контексті самоактуалізацї / Н.П. Гуральник // Науковий часопис НПУ імені М.П. Драгоманова. Серія 14. Теорія і методика мистецької освіти: Зб. наукових праць - Київ : НПУ імені М.П. Драгоманова, 2013 Вип.14 (19). Частина 1. С.243-246.

5. Котова Л.М. Емоиійна стійкість як засіб формування інструментально-виконавської надійності у студентів музично-педагогічних ЗВО : автореф. дис. на здобуття наук. ступеня канд. пед. наук: спец. 13.00.02 «Теорія та методика музичного навчання» / Ліна Миколаївна Котова. Київ, 2001. $14 \mathrm{c}$.

6. Рудницька О.П. Педагогіка загальна та мистеиька : навч. посіб. Київ, 2002. 269с.

7. Цагарелли Ю.А. Психология музыкально-исполнительской деятельности : автореф. дис. д-ра психол. наук : спец. 19.00.03 / Ю.А. Цагарелли. Казань, 1989. 39 с.

8.Юник Д.Г. Виконавська надійність як основа сиенічної діяльності митиів музичного мистецтва / Д. Г.Юник // Наукова школа Г.М. Падалки. Колективна монографія / під наук. ред. А.В. Козир. Київ : НПУ імені М.П. Драгоманова, 2011. 377 с.

9. Юник Д.Г. Завадостійкість майбутніх учителів музики у проиесі інструментальновиконавської діяльності / Д.Г. Юник // Рідна школа. - Київ : Освіта, 2012. - Вип. 8/9. С.52-56.

\section{Про автора:}

Чень Веньфен, аспірантка факультету мистецтв Національного педагогічного університету імені М.П. Драгоманова (Київ, Україна); ORCID: 0000-0001-8358-8599, e-mail: 272969079@qq.com

\section{Piano reliability of students of art faculties of pedagogical universities in the psychological and pedagogical aspect}

The article discusses the essence of the piano reliability of students of art faculties of pedagogical universities. The urgency of the problem is determined in the context of a clearly defined educational trend in the field of permanent optimization of professional training for future musician teachers, the activation of innovative technologies in the field of pedagogy of art, and the constant methodological updating of pedagogical science. It has been established that the inability of future music educators to quality piano performance can lead to unjustified losses and shortcomings directly in the process of future professional activity. As a result of the analysis of scientific and theoretical literature on the issue of research, the reliability of musical performance is outlined as an integral part of the performing skills of an instrumental musician. The definition and content of the performing reliability of students of art faculties of pedagogical universities by leading modern scientists is given and analyzed. The influence of stressful situations on the quality of the piano playing in the process of public performance has been investigated. It is proved that the reliability of student performance of piano works depends on his psychological and emotional sphere, which is responsible for the stage behavior of a person, adapting it to the emotional conditions of demonstrating the results of previous work. The content of two main varieties of emotional stress is disclosed - eustress and distress. The basic steps of the formation of piano reliability in the plane of purposeful organization of student-oriented piano education of students are presented. The author's definition of the phenomenon under study as an integral quality acquired in the process of piano training by students of the faculties of art at pedagogical universities is developed, which ensures the emotional and stressful conditions of a public piano 
game that fully and efficiently fulfil the task set during the previous piano training with the aim of revealing the artistic-figurative content of the musical works.

Keywords: performing reliability; students of art faculties of pedagogical universities; emotional stress; stress; distress; personality-oriented piano training.

\section{References}

1. Antonova O.E. Teoretichni ta metodichni zasadi navchannya pedagogichno obdarovanih studentiv. Zhitomir : Vid-vo ZhDU imeni I.Franka, 2007. 471s.

2. Burska O.P. Metodichnyi osnovi rozvitku muzichno-vikonavskogo mislennya studentiv u protsesi fortepiannoyi pidgotovki: Dis.... kand. ped. nauk:13.00.02 / O.P. Burska. - Vinnitsya : Vinnitskiy derzh. ped. un-t im. M. Kotsyubinskogo, 2004. 239s.

3. Grinchuk I., Burska O. Problemi muzichnogo mislennya: teoriya i metodika rozvitku: Navch.-metod. posibnik / I.Grinchuk, O.Burska. - Ternopil : Pidruchniki i posibniki, 2008. 224s.

4. Guralnik N.P. Improvizatsiyni uminnya maybutnogo vchitelya muziki v kontekstI samoaktualizatsiyi / N.P. Guralnik // Naukoviy chasopis NPU ImenI M.P. Dragomanova. Seriya 14. Teoriya i metodika mistetskoyi osviti : zb. naukovih prats - KiYiv: NPU imeni M.P. Dragomanova, 2013 - Vip.14 (19). Chastina 1. S.243-246.

5. Kotova L.M. Emotsiina stiikist yak zasib formuvannia instrumentalno-vykonavskoi nadiinosti u studentiv muzychno-pedahohichnykh: avtoref. dys. na zdobuttia nauk. stupenia kand. ped. nauk: spets. 13.00.02 «Teoriia ta metodyka muzychnoho navchannia» / Lina Mykolaivna Kotova - Kyiv , 2001. 14 s.

6. Rudnitska O.P. PedagogIka zagalna ta mistetska: navch. posib. Kyiv, 2002. 269s.

7. Tsaharelly Yu.A. Psykholohyia muzыkalno-yspolnytelskoi deiatelnosty: avtoref. dys. d-ra psykhol. nauk: spets. 19.00.03 / Yu.A. Tsaharelly - Kazan, 1989. 39 s.

8. Yunyk D.H. Vykonavska nadiinist yak osnova stsenichnoi diialnosti mysttsiv muzychnoho mystetstva // Naukova shkola H.M. Padalky. Kolektyvna monohrafiia / pid nauk. red. A.V. Kozyr / Dmytro Hryhorovych Yunyk - Kyiv: NPU imeni M.P. Dragomanova, 2011. 377 s.

9. Yunik D. H. Zavadostiykist maybutnih uchiteliv muziki u protsesi instrumentalno-vikonavskoyi diyalnosti / D. H. Yunik // Ridna shkola. - Kyiv: OsvIta, 2012. - Vip. 8/9. S.52-56.

About the author:

Chen Wenfeng, postgraduate student at the Faculty of Arts, National Pedagogical Dragomanov University (01054, Kyiv, Ukraine); ORCID: 0000-0001-8358-8599, e-mail: 272969079@qq.com 